Caminhos da Crítica 


\title{
Caminhos do Crítico
}

\author{
Antonio Carlos Secchin*
}

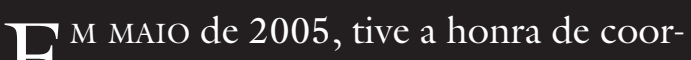
¿denar, na Academia Brasileira de Letras, no Rio de Janeiro, um ciclo de palestras intitulado "Caminhos do Crítico".

A proposta era original: em vez de ouvirmos críticos discorrerem sobre determinado objeto de sua especialidade, solicitamos a quatro consagrados nomes - Alfredo Bosi, Benedito Nunes, Leyla PerroneMoisés e Eduardo Portella - que elaborassem uma espécie de roteiro de suas próprias trajetórias, registrando os anos de formação, as filiações e dissensões teóricas, as encruzilhadas metodológicas, o estabelecimento, enfim, de um balanço de suas biografias intelectuais, num auto-retrato que fornecesse subsídios e reflexões de relevância para todos os que, posteriormente, viessem a se debruçar sobre a contribuição de nossos quatro convidados aos estudos literários no país.

O público, integrado em sua grande maioria por estudantes das Faculdades de Letras do Rio de Janeiro, logo indagou se tão rico material não poderia tornar-se acessível a um contingente maior de interessados, para além das centenas de pessoas que prestigiaram o evento. A resposta a essa demanda materializa-se, agora, na publicação integral das conferências, numa feliz iniciativa que enlaça a revista ESTUDOS AVANCADOS da USP e a Academia Brasileira de Letras, numa promessa de novas e fecundas parcerias.

*É doutor em Letras e professor titular de Literatura Brasileira da Universidade Federal do Rio de Janeiro (UFRJ). Poeta e ensaísta com vários livros publicados, é membro da Academia Brasileira de Letras. 